\title{
Food-Carbon Trade-offs between Agriculture and Reforestation Land Uses under Alternate Market-based Policies
}

\author{
Stacey Paterson $^{1,2}$ and Brett Anthony Bryan ${ }^{1}$
}

\begin{abstract}
Understanding the effects of payments on the adoption of reforestation in agricultural areas and the associated food-carbon trade-offs is necessary to inform climate change policy. Economic viability of reforestation under payment per hectare and payment per tonne schemes for carbon sequestration was assessed in a region in southern Australia supporting 6.1 Mha of rain-fed agriculture. The results show that under the median scenario, a carbon price of $27 \mathrm{~A} \$ / \mathrm{tCO}_{2}$-e could make onethird of the study area (nearly $2 \mathrm{Mha}$ ) more profitable for reforestation than agriculture, and at $58 \mathrm{~A} \$ / \mathrm{tCO}_{2}$-e all of the study area could become more profitable. The results were sensitive to variation in carbon risk factor, establishment costs, and discount rates. Pareto-optimal land allocation could realize one-third of the potential carbon sequestration from reforestation (16.35 $\mathrm{MtCO}_{2}-\mathrm{e} / \mathrm{yr}$ at a carbon risk factor of 0.8) with a loss of less than one-tenth $(107.89 \mathrm{~A} \$ \mathrm{M} / \mathrm{yr})$ of the agricultural production. Both payment schemes resulted in efficiencies within $1 \%$ of the Pareto-optimum. Understanding food-carbon trade-offs and policy efficiencies can inform carbon policy design.
\end{abstract}

Key Words: agriculture; agroecosystem; carbon sequestration; ecosystem services; food security; land use; payment; policy; reforestation

\section{INTRODUCTION}

Land clearance and agricultural production have increased emissions of climate-changing atmospheric greenhouse gases from agroecosystems (Foley et al. 2005). However, agricultural landscapes can also have an important role in abating greenhouse gas emissions and mitigating climate change (Palm et al. 2010). Reforestation of agricultural land can mitigate climate change through sequestration of carbon in biomass and soils, or through the production of bioenergy (Obersteiner et al. 2010). The trade-off from reforestation is the reduced availability of land for production of food and fiber (Smith et al. 2010). Direct competition for finite land resources creates a tight link between carbon sequestration and agricultural commodities (Golub et al. 2009, Smith et al. 2010). Hence, policies designed to mitigate climate change by promoting reforestation can put upward pressure upon food prices (Wise et al. 2009) with subsequent implications for global human nutrition. To avoid these adverse outcomes, climate policy needs to consider potential food-carbon tradeoffs between agricultural and reforestation land uses in rural landscapes.

The potential for carbon and ecosystem service market policies to alter the relative profitability of land uses and motivate large scale reforestation has been recognized (Alig et al. 2010, Crossman et al. 2011). The impact of market-based climate policy on reforestation of agricultural land depends on many factors with expected profitability critical among these (Irwin and Geohegan 2001, Lubowski et al. 2008). Several assessments of the impact of market policies on reforestation and carbon sequestration have been made (Plantinga et al. 1999, Stavins 1999, Lubowski et al. 2006, Harper et al. 2007,
Hunt 2008, Lawson et al. 2008, Polglase et al. 2008, 2011). As opportunity costs of alternative land uses have often been considered, these studies have implicitly assessed trade-offs between land uses. Although much attention has been paid to food production impacts from bioenergy policy (Bryan et al. $2010 b$, Tilman et al. 2009), there have been few explicit assessments of the potential impact on food production of policies encouraging reforestation for carbon sequestration.

Food-carbon trade-offs resulting from reforestation of agricultural land will depend upon the spatially varying ability of land areas to sequester carbon relative to their agricultural productivity (Crossman et al. 2011). The design of marketbased policy, specifically whether payments are heterogeneous (spatially-targeted payment per tonne of carbon sequestered) or homogeneous (payment per unit area reforested), can affect policy efficiency and the nature of the food-carbon trade-offs realized by carbon payments. It is well established that spatial targeting based on both costs and benefits results in more efficient outcomes than targeting based upon costs or benefits alone, when considering single contracts, and the extent of this efficiency gain is dependent upon the relative variance of costs and benefits (Babcock et al. 1997, Wu and Bogess 1999, Ferraro 2003, Newburn et al. 2005, Wätzold and Drechsler 2005, Crossman and Bryan 2009, Chen et al. 2010, Stoms et al. 2011).

West et al. (2010) highlighted the influence of spatial arrangement of land use on efficiency gains for managing food-carbon trade-offs at a global scale. The potential influence of land use allocation on efficiency at finer spatial scales, e.g., landscape scale, may also be substantial (DeFries et al. 2004) because spatial heterogeneity has been found at 
this scale, in carbon sequestration (Cantarello et al. 2011), agricultural production (Bryan et al. 2009), and land use profitability (Bryan et al. 2011a). Improving the scale and resolution of biophysical and economic modeling, including the accurate representation of spatial heterogeneity, can better estimate the food-carbon trade-offs likely to result from changes in economic viability of reforestation, caused by market-based climate policy (Van der Werf and Peterson 2009). This can inform the design of more efficient policy instruments, which are better able to minimize adverse impacts of reforestation on food production.

Two main techniques have been used to quantify the tradeoffs between competing land uses at a landscape scale. Scenario analysis has been used to quantify spatially-explicit trade-offs between food production and greenhouse gas mitigation through bioenergy land uses (Bryan et al. 2010a, Thomson et al. 2010), but only for a limited number of spatial and policy options. Alternatively, Polasky et al. (2008) searched for efficient land use combinations to maximize species conservation for a range of levels of economic returns, and vice versa, resulting in a Pareto-optimal frontier of spatially explicit land use arrangements. Higgins et al. (2008) and Nelson et al. $(2008,2009)$ employed similar methods to highlight the trade-offs between carbon sequestration and other ecosystem services across a spectrum of policy options, e.g., a range of target levels under alternative targeting strategies. However, no studies have explicitly assessed the food-carbon trade-offs of reforestation under alternative market-based policies on a landscape scale for informing efficient policy design.

In this study, we quantified food-carbon trade-off curves at a landscape scale under two commonly used market-based carbon policy instruments: payment per tonne, and payment per hectare. Using modeled, spatially explicit $(2 \mathrm{~km} \times 2 \mathrm{~km}$ land units) estimates of agricultural production and carbon sequestration potential, we calculated layers of profit from agriculture and from reforestation under each payment scheme for carbon prices ranging from 1 to $200 \$ / \mathrm{tCO}_{2}$-e (tonnes of carbon dioxide equivalent; all dollar figures in Australian dollars) and identified the most profitable land use. We calculated Pareto-optimal production frontiers that quantify changes in carbon sequestration and food production for production-maximizing land allocation for all possible levels of carbon sequestration. We compared the efficiency of foodcarbon trade-off curves against the production frontiers. We tested the sensitivity of economic viability of reforestation, policy efficiency, and food-carbon trade-offs to variation in carbon risk discounting, establishment costs, transaction and maintenance costs, and economic discount rates. We discuss the implications of the results for carbon policy design.

\section{METHODS}

\section{Study area description}

The 11.9 million ha Lower Murray case study area includes the South Australian Murray-Darling Basin Natural Resources Management Board region (SAMDB), and the Mallee and Wimmera Catchment Management Authority areas (Fig. 1). Climate ranges from semiarid in the north of the study area experiencing just $300 \mathrm{~mm} /$ year rainfall, through Mediterranean, to cool temperate in the south (up to $900 \mathrm{~mm} / \mathrm{yr}$ rainfall). Soils are typically nutrient-deficient. The two dominant land uses are rain-fed agriculture and nature conservation, with small (1.6\%) but economically important areas of irrigated agriculture along the River Murray. Rain-fed agricultural production ranges from continuous sheep grazing for meat and wool in the drier northern and central SAMDB and northern Mallee regions, to continuous cereal cropping in the wetter Wimmera region, with cropping-grazing rotations employed in between. Wheat yields range from $0.68 \mathrm{t} / \mathrm{ha}$ to $2.18 \mathrm{t} / \mathrm{ha}$ (average $0.76 \mathrm{t} / \mathrm{ha}$ ). Net economic returns from agriculture range from 6 to $479 \$ /$ ha/yr (average $179 \$ / \mathrm{ha} / \mathrm{yr}$; Bryan et al. 2011a). We confined our assessment of food-carbon tradeoffs to the 6.1 million ha of land currently used for rain-fed agriculture (Fig. 1). We tessellated this area into $2 \mathrm{~km} \times 2 \mathrm{~km}$ grid cells for analysis, thereby creating 15,241 individual land units, each 400 ha in area.

Fig. 1. Location and land use in the Lower Murray study area.

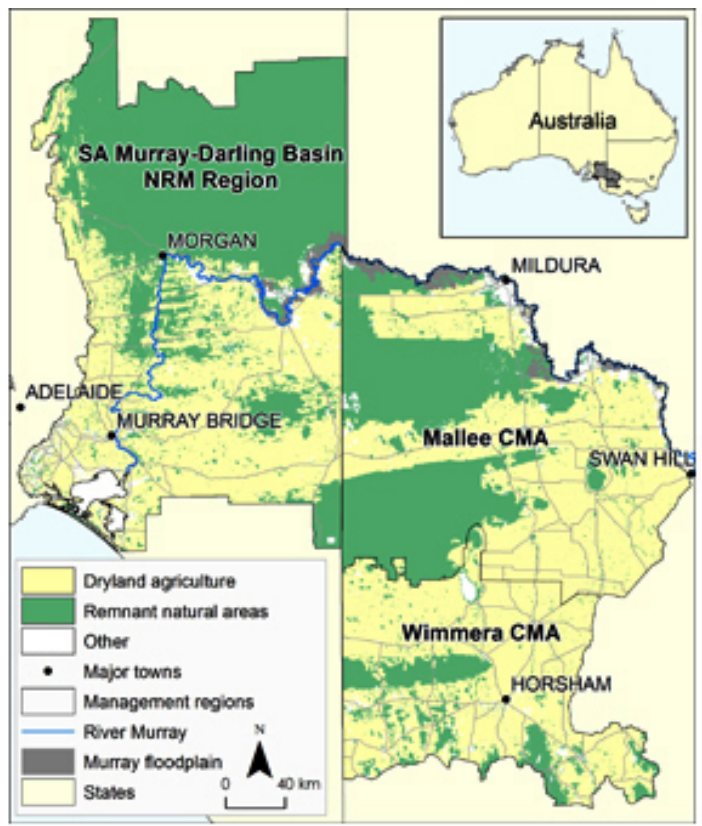


Table 1. Summary of model parameters assessed in this study (- used in low cost scenario, ${ }^{\dagger}$ used in median scenario, + used in high cost scenario).

\begin{tabular}{llll}
\hline \hline Parameter & Units & Symbol & Values \\
\hline Carbon price & $\$ /$ tCO2-e & $p$ & $1,2, \ldots, 200$ \\
Carbon risk discounting factor & Factor & $R$ & $1.0,0.8^{\dagger}, 0.6$ \\
Establishment costs & $\$ /$ ha & $e c$ & $1150^{-}, 2000^{\dagger}, 6000^{+}$ \\
Transaction and maintenance costs & $\$ /$ ha/yr & $t m c$ & $40^{-}, 70^{\dagger}, 100^{+}$ \\
Economic discount rates & $\%$ & $r$ & $3,7^{\dagger}, 11,15$ \\
Total number of years in the analysis & Years & $T$ & 64 \\
\hline
\end{tabular}

\section{Agricultural production}

We used net economic returns to represent the value of agricultural production. The advantage is that it provides a single measure of the production of different agricultural products, i.e., wheat and other crops, sheep meat, and wool, that reflects the value society places upon them.

Spatial estimates of net economic returns to agriculture were compiled in two stages. First, the frequency of rotation of different farming system phases, i.e., wheat, lupins, and sheep, were derived from agricultural census data and catchment scale land use mapping, and used to characterize the spatial distribution of farming system rotations. Second, agricultural profit was calculated using a profit function. The profit function includes information on yield, price, and costs of production by Statistical Local Area (SLA) derived from agricultural census and state government Gross Margin Handbooks. The SLA-based estimates were then smoothed using pycnophylactic (mass-preserving) interpolation, and combined with the spatial distribution of farming rotation systems to create a layer of annual expected profit from farming systems (Bryan et al. 2009, 2011a). This was converted to Net Present Value (NPV) over the analysis period of 64 years (2006-2070). The period to 2070 was selected to account for the long time period required for carbon to be sequestered.

\section{Spatial prediction of forest growth and carbon sequestration}

The Physiological Principles to Predict Growth (3-PG) model (Landsberg and Waring 1997) was used to estimate reforestation rates over the study area. 3-PG takes soil and climatic data inputs, and knowledge of the physiology of tree species to predict stand biomass, water use, and available soil water on a monthly basis. To model tree growth and carbon sequestration in 3-PG, we used a species growth parameter set for a mallee tree species (Eucalyptus kochii, CSIRO, unpublished data) well adapted to the climate in our region, but not native to the study area.

We assembled spatial information on broad soil class from state government databases. We used representative soil pit data to derive maximum available soil water (ASW) for each soil class. We also specified fertility rating $=0.8$, minimum ASW $=0 \mathrm{~mm}$, initial ASW $=60 \mathrm{~mm}$, seedling mass $=5 \mathrm{~g}$, planting density of 1000 stems/ha. We created spatial layers of mean monthly rainfall, temperature (maximum and minimum), and solar radiation using the ESOCLIM climate model. We used 3-PG spatial to model the spatial distribution of stand growth over a time period of 64 years. Forest productivity was modeled at a spatial resolution of $200 \mathrm{~m} \mathrm{x}$ $200 \mathrm{~m}$ grid cells then converted to the $2 \mathrm{~km} \times 2 \mathrm{~km}$ resolution using bilinear resampling.

Carbon sequestration is dependent upon the growth of biomass that varies over time. We used the von Bertalanffy-ChapmanRichards (vBCR) growth function (Richards 1959, Zhao-gang and Feng-ri 2003) to capture nonlinear (sigmoidal) rates of biomass growth and carbon sequestration over time as modeled by 3-PG. The growth curve has been commonly used to predict growth patterns in forestry (Alexandrov 2008). We fit a vBCR growth function to the 3-PG modeled growth using a genetic algorithm. Stand carbon sequestration was derived from stand biomass in carbon dioxide equivalent terms (tonnes $\mathrm{CO}_{2}$-e/ha) and the annual carbon increment $Y_{t}\left(\mathrm{tCO}_{2}\right.$-e/ha/yr) was calculated.

\section{Economic scenarios and sensitivity analysis}

We assessed food-carbon trade-offs associated with policy alternatives using a range of carbon prices under median values for carbon sequestration risk discounting, establishment costs, transaction and maintenance costs, and economic discount rates (Table 1). We also tested the sensitivity of the results to variation in these parameters.

\section{Carbon sequestration risk discounting}

Cacho et al. (2005) highlighted the importance of discounting carbon biosequestration compared to other more permanent methods of reducing atmospheric greenhouse gas concentrations. When carbon is sequestered in organic material, there is some risk that it will be released back into the atmosphere through a range of processes, e.g., fire, harvesting, land clearance. In contrast, avoided emissions are effectively avoided forever. In addition, a number of other factors also contribute to uncertainty in carbon sequestration including modeling error and moral hazard. We accounted for 
this suite of risk factors by discounting the 3-PG-modeled carbon sequestration rates. We used a median carbon risk discount factor of 0.8 such that for each tonne of $\mathrm{CO}_{2}$-e sequestered (as modeled by 3-PG), only $0.8 \mathrm{tCO}_{2}$-e could be sold in a carbon market. We also tested the sensitivity of the model at risk discount factors of 0.6 and 1.0 (Table 1).

\section{Carbon prices}

The range of carbon prices in this study (Table 1) was designed to enable analysis of the full trade-off curve ranging from no economically viable areas for reforestation to all areas becoming viable. Increasing carbon price $\left(\$ / \mathrm{tCO}_{2}\right.$-e) in $\$ 1$ increments captured the shape of the supply curve and the production frontier.

\section{Establishment costs}

Estimates of establishment costs of reforestation (Table 1) using two different methods, i.e., direct seeding and tube stock planting, were obtained from Greening Australia (J. McGregor, personal communication, January 17, 2011). The estimates included maintenance costs for two years postplanting, and are conservative, being based upon costs in a higher rainfall $(600+\mathrm{mm} / \mathrm{yr})$ area with good soil. At a cost of $1150 \$ /$ ha, direct seeding was significantly cheaper than planting seedling tube stock at $6000 \$ /$ ha. However, planting with tube stock increases survivorship and control of the canopy layers. We also used a median estimate of establishment costs of 2000 \$/ha estimated from the South Australian Government's large scale River Murray Forest restoration program (Crossman et al. 2011).

\section{Ongoing transaction and maintenance costs}

Annual transaction and maintenance costs also accrue for the management of reforested areas (Table 1). Transaction costs include a range of administrative activities associated with carbon sequestration, trading, and accounting. Maintenance costs include feral pest and disease management, fire risk management, and a range of other activities required to maintain reforested stands.

\section{Economic discount rates}

We assessed five discount rates (Table 1). The rates $r=3 \%$ and $11 \%$ encompass the minimum and maximum cash rate set by the Reserve Bank of Australia since September 1991 (RBA 2010). Variation in discount rate within this range is likely. The rate $r=15 \%$ was also included as a more extreme case. Although higher than commercial interest rates, this interest rate reflects the case in which landholders have a strong preference for income in the present, over income in the future.

\section{Policy alternatives}

We calculated food-carbon trade-offs under two alternative payment schemes: payment per tonne, and payment per hectare. The trade-off models were implemented in the General Algebraic Modeling System (GAMS). We solved the models for each combination of carbon risk factors, carbon prices, discount rates, transaction and maintenance costs, and establishment costs (Table 1). In both policy scenarios, payments were made annually using the ideal payment system' of Cacho et al. (2003), which accounts for the variation in rates of tree growth/carbon sequestration over time. We have not considered the costs of carbon monitoring and verification in either policy alternative. The magnitude of these costs is sensitive to policy design (see Discussion).

\section{Payment per tonne}

The payment per tonne scheme incorporates spatial heterogeneity in carbon sequestration consistent with the Kyoto Protocol, and the Clean Development Mechanism. One of the major drawbacks of this scheme is the transaction costs associated with carbon monitoring, verification, and accreditation. Typically, carbon sequestration monitoring is undertaken through a combination of remote sensing, modeling, and on-ground measurement. As an example of the potential impact of these costs, most participants in 'Activities Implemented Jointly' of the United Nations Framework Convention on Climate Change were not willing to monitor carbon sequestration because of the high costs (Cacho et al. 2005). Here, we assume landholders are paid annually for the amount of carbon they sequester $\left(Y_{t}\right)$ as modeled using the 3PG spatial estimates and the vBCR growth curve described above. Under the payment per tonne scheme, the economic return to landholders was calculated in NPV terms as:

$$
N P V=\sum_{t=1}^{T} \frac{p Y_{t} R-t m c}{(1+r)^{t}}-e c
$$

$p$ is the price per tonne of carbon sequestration and $p Y_{t} \mathrm{R}$ represents the cash inflow from reforestation in each period $t$ given a carbon risk discounting factor $R, t m c$ represents the annual transaction and maintenance costs, $r$ is the discount rate, and $T$ denotes the total number of years (64) in the analysis.

\section{Payment per hectare}

Under the payment per hectare scheme, payment for carbon sequestration was paid at uniform production levels equal to the regional average sequestration rate per hectare (10.06 $\mathrm{tCO}_{2}$-e/yr). This is similar to other schemes such as the Canadian Permanent Cover Program. This style of payment has potential to reduce transaction costs and enhance payment equity between landholders (Wu and Boggess 1999). To arrive at the regional average carbon sequestration rate $(Y)$, we calculated the average annual rate of carbon sequestration over time based on the 3-PG model estimates over the 64-year time horizon then averaged this across all rain-fed agriculture grid cells. Under this scheme, economic returns to landholders were calculated as: 


$$
N P V=\sum_{t=1}^{T} \frac{p \bar{Y} R-t m c}{(1+r)^{t}}-e c
$$

\section{Pareto-optimal benchmark}

To determine the efficiency of the two payment schemes and quantify the food-carbon trade-offs, we calculated Paretooptimal production frontiers. The Pareto frontiers show potential production bundles resulting from all possible efficient combinations of land use. An efficient land use allocation is one in which no units of land could be reallocated to increase production of one good without decreasing production of the other. The following steps were used to calculate each Pareto frontier:

1. For each land unit, calculate the ratio of potential agricultural production measured in economic profit $(\$ /$ ha) to potential carbon sequestration $\left(\mathrm{tCO}_{2}-\mathrm{e} / \mathrm{ha}\right)$ under reforestation;

2. Rank land units in increasing order of food-carbon ratio;

3. In rank order, calculate and graph the total agricultural production (\$) and carbon sequestration $\left(\mathrm{tCO}_{2}\right.$-e/ha) in the study area as each land unit is sequentially converted to reforestation.

\section{Economic viability of reforestation, food-carbon trade- offs, and efficiency}

We quantified and mapped the net economic returns to reforestation, i.e., returns to reforestation minus returns to agricultural production, under the full range of carbon prices. The economically viable area of reforestation, i.e., where returns to reforestation exceed those from agriculture, and carbon sequestration supply were graphed against carbon price. Trade-off curves track the aggregate change in food production and carbon sequestration from economically viable areas with carbon price. To quantify policy efficiency, the area under the trade-off curves for both the payment per tonne and payment per hectare schemes was calculated and compared against the area under the Pareto-optimal production frontier. Sensitivity analysis was then conducted to assess the influence of model parameters on (a) economically viable area, and (b) the efficiency of payment schemes and the nature of food-carbon trade-offs.

\section{RESULTS}

\section{Carbon sequestration and economically viable areas}

Modeled carbon sequestration rates ranged from annual averages of $7.31 \mathrm{t} / \mathrm{ha} / \mathrm{yr}$ to $16.48 \mathrm{t} / \mathrm{ha} / \mathrm{yr}$ (mean $10.06 \mathrm{t} / \mathrm{ha} / \mathrm{yr}$; Fig. 2). Payment per hectare and payment per tonne systems produced similar economically viable areas. For each payment system, economically viable areas and carbon supply curves have four inflection points that occur at similar prices and levels of sequestration under the median scenario (Fig. 3).
These points mark shifts in the economic viability of reforestation in response to changes in price. The greatest shift in economic viability occurs as the price for carbon increases from $20 \$ / \mathrm{tCO}_{2}$-e to $27 \$ / \mathrm{tCO}_{2}$-e. Nearly one-third (32.63\%) of the land in the study areas becomes more profitable under reforestation than under agriculture at $27 \$ / \mathrm{tCO}_{2}$-e. A further increase in carbon price to $32 \$ / \mathrm{tCO}_{2}$-e has much less of an impact on the relative profitability of reforestation and agriculture. For prices greater than $32 \$ / \mathrm{tCO}_{2}$-e the rate of change in economic viability of reforestation is higher and remains constant up to around $52 \$ / \mathrm{tCO}_{2}$-e where nearly all of the study area becomes more profitable for reforestation than for agriculture. The supply curves for carbon sequestration follow similar patterns to the economically viable area curves (Fig. 3).

Fig. 2. Total carbon sequestration in the study area over 64 years as modeled by $3-\mathrm{PG}$.

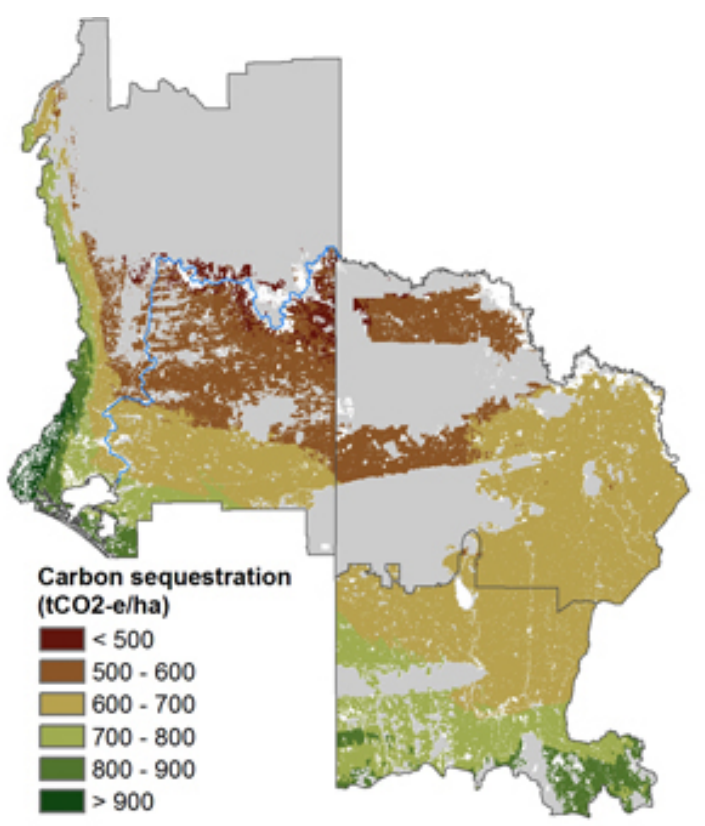

The spatial distribution of net economic returns to reforestation areas under the two payment schemes is presented for the median scenario in Figure 4. Although the general pattern in net economic returns is similar, differences occur at all carbon prices. Differences arise because under the payment per hectare scheme, the least profitable agricultural land becomes economically viable first. Under a payment per tonne scheme the first areas that become economically viable have both low returns to agriculture and high carbon sequestration capacity. 
Fig. 3. Economically viable area for reforestation and carbon sequestration supply curve under a range of carbon prices for the median scenario $(\mathrm{R}=0.8, \mathrm{ec}=\mathrm{A} \$ 2000 / \mathrm{ha}$, $\mathrm{tmc}=\mathrm{A} \$ 70 / \mathrm{ha} / \mathrm{yr}, \mathrm{r}=7 \%)$. Carbon sequestration is an annual average value over 64 years.
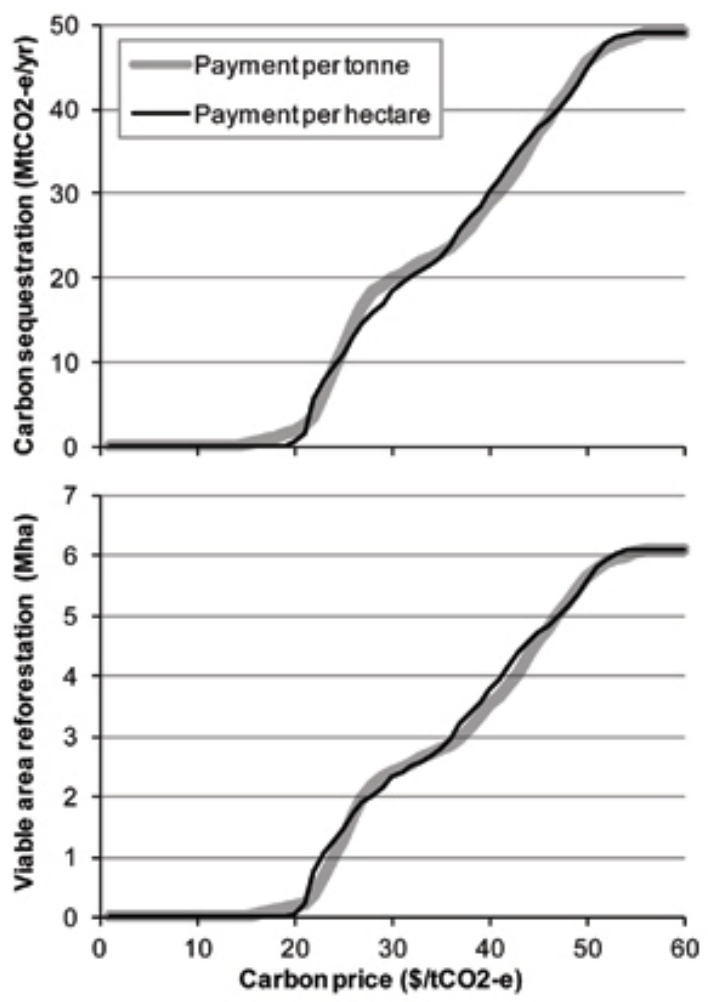

Policy efficiency and food-carbon trade-offs

Food-carbon trade-off curves were convex in shape. As the carbon price increases, and more carbon is sequestered in reforested land, the marginal cost in terms of lost agricultural production increases. Relatively, larger amounts of carbon can be sequestered for minimal impact on food production. For the Pareto-optimum production frontier, one-third of total average annual carbon sequestration potential from reforestation $(16.35 \mathrm{MtCO} 2-\mathrm{e} / \mathrm{yr}, R=0.8)$ can be achieved with a loss of $9.83 \%$ of annual agricultural profits $(107.89 \$ \mathrm{M} /$ yr). The food-carbon trade-off curves of both payment schemes are very similar, and both are extremely close to the Pareto-optimum suggesting high efficiency in land use allocation under both payment systems. The efficiency of the payment per tonne and payment per hectare schemes under the median scenario compared to the Pareto-optimal was $99.03 \%$ and $99.56 \%$, respectively (Fig. 5).

\section{Sensitivity analysis}

Variation in establishment costs, transaction and maintenance costs, and discount rates affects the profitability of reforestation compared with agriculture (Fig. 6). Increased costs significantly increase the carbon price required to make reforestation profitable and higher discount rates exaggerate this effect. Of these costs, establishment costs have a much stronger influence than transaction and maintenance costs on the carbon price required to make reforestation a profitable option for any land unit. High discount rates $(11 \%, 15 \%)$ decrease the relative profitability of reforestation because of the lag time associated with tree growth and discounted returns from carbon sequestration (Fig. 6).

Increasing the establishment costs and discount rate decreased the efficiency of reforestation of economically viable areas, but only under the payment per tonne scheme (Fig. 7). The greatest deviation from the Pareto-optimal occurs when high establishment costs $(6000 \$ / \mathrm{ha})$, high transaction and maintenance costs (100\$/ha/year), and high discount rates (15\%) were considered simultaneously. This combination of parameters changes the spatial distribution of economically viable areas, and results in less efficient land allocation and associated production outcomes. The high cost and high discount rate scenario achieved $92.79 \%$ efficiency relative to the Pareto-optimal production frontier. The low cost $(e c=$ $1150 \$ / \mathrm{ha}, t m c=40 \$ / \mathrm{ha}$ ) and low discount rate (3\%) scenario achieved $99.82 \%$ efficiency. The efficiency of the per hectare payment system was unaffected by changes in these economic parameters (Fig. 7).

\section{DISCUSSION}

\section{Economic viability of reforestation and food-carbon trade-offs}

The calculation of economic returns shows that large areas of agricultural land could become more profitable as carbon sinks at relatively modest carbon prices. For example, under the median scenario, a carbon price of $27 \$ / \mathrm{tCO}_{2}$-e makes nearly one-third of the study area (1.99 Mha) more profitable for carbon sequestration. At $58 \$ / \mathrm{tCO}_{2}$-e all of the study area is more profitable. However, these results are very sensitive to the choice of model parameters with the carbon risk factor, establishment costs, and discount rates all having significant effects on the economically viable area for reforestation and the resultant carbon supply curves. Although the results are striking, they should not be taken as a prediction of reforestation extent under a carbon market. Rather, these insights are most effectively used in informing policy design, and in providing direction for future research. 
Fig. 4. Spatial distribution of net economic returns (annualized) to reforestation under the payment per tonne and payment per hectare schemes for a range of carbon prices using the median scenario parameter values $(\mathrm{R}=0.8, \mathrm{ec}=\mathrm{A} \$ 2000 / \mathrm{ha}, \mathrm{tmc}=$ $\mathrm{A} \$ 70 / \mathrm{ha} / \mathrm{yr}, \mathrm{r}=7 \%)$.

\section{0 \$/tCO2-e}

Payment per tonne

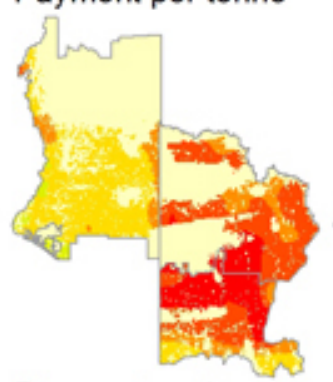

Payment per hectare

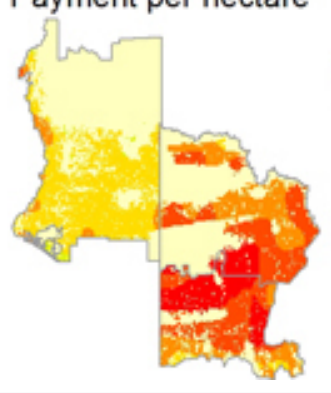

$30 \$ / \mathrm{tCO}-\mathrm{e}$
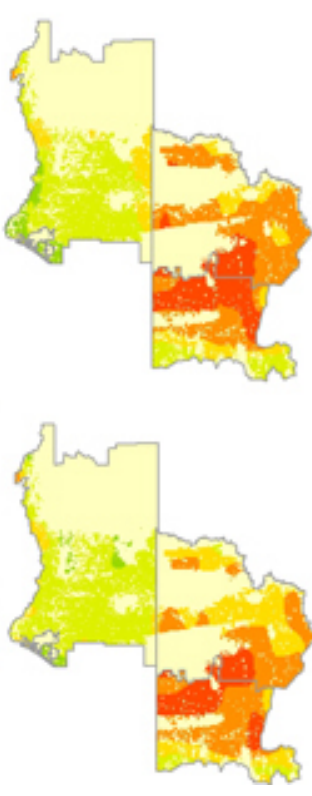

$40 \$ /$ tCO2-e
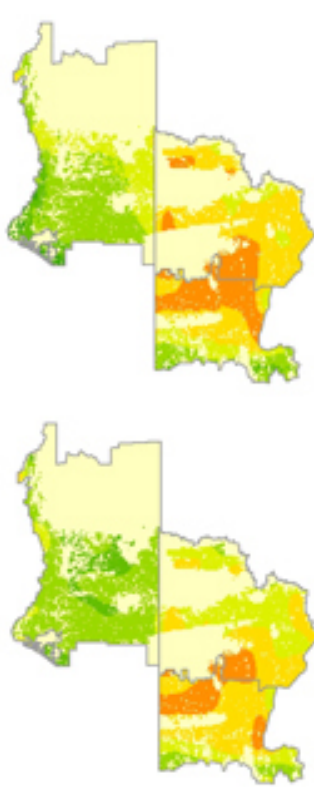

$50 \$ /$ tCO2-e

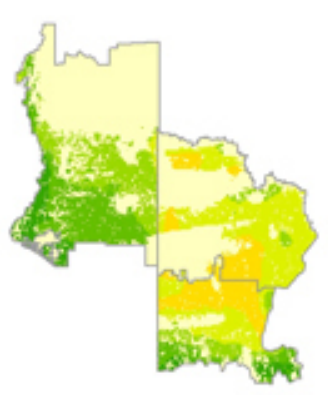

Net annualized

returns (\$/ha/yr)

$\square<-300$

$-300-200$

$-200 \cdots-100$

$-100=0$

$0-100$

$100-200$

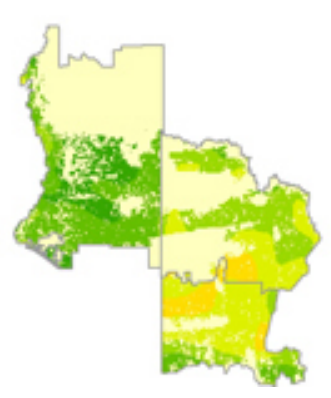

$200-300$

$>300$

Other

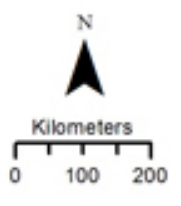

Fig. 5. Food-carbon trade-offs for the payment per tonne and payment per hectare schemes. Trade-offs were calculated using the median scenario parameter values $(\mathrm{R}=$ $0.8, \mathrm{ec}=\mathrm{A} \$ 2000 / \mathrm{ha}, \mathrm{tmc}=\mathrm{A} \$ 70 / \mathrm{ha} / \mathrm{yr}, \mathrm{r}=7 \%)$ and values of carbon sequestration are an annual average over a 64-year period.

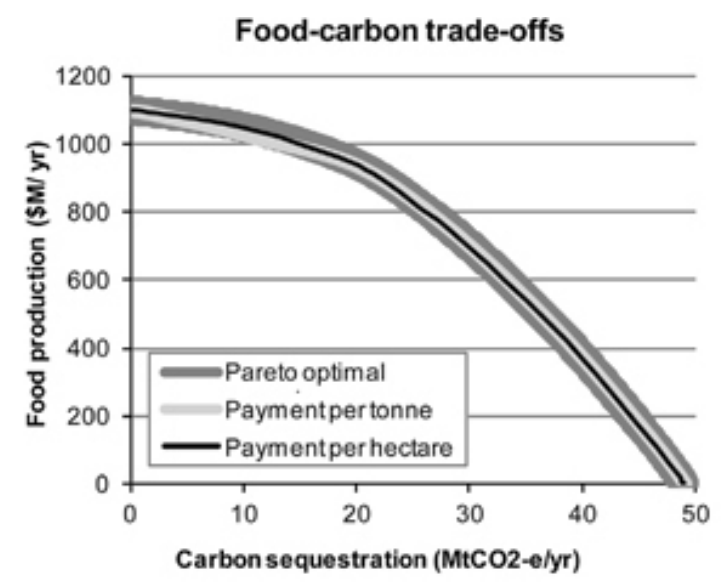

The land use system analyzed in this paper is land-limited such that increased production of one good (carbon) reduces production of the other (food). Land units show spatial heterogeneity in the productivity of agriculture and carbon sequestration. Convex trade-off curves presented an opportunity through efficient land allocation, to sequester roughly one-third of the total carbon at a cost of less than onetenth of the total agricultural production. The converse risk is that maximally inefficient land allocation could result in the other two-thirds of the total carbon coming at a cost of ninetenths of the agricultural production. The opportunity to use reforestation to sequester significant amounts of carbon with minimal impacts on agricultural output can be realized, and the risk of reforestation significantly reducing agricultural production can be avoided, through efficient policy design.

\section{Policy efficiency}

A priori, we expected the payment per tonne scheme to be the more efficient payment scheme because it links both heterogeneous costs (foregone agricultural profits) and heterogeneous benefits (tonnes of carbon sequestered) to a monetary incentive for the landholder. Conversely, the payment per hectare scheme links heterogeneous costs and a homogeneous proxy for benefits (regional mean carbon sequestration) to the landholder's monetary incentives. The use of a homogeneous proxy to determine payment rates for a heterogeneous benefit introduces the potential for inefficient land use allocation. However, under median parameters, both payment schemes led to production outcomes with efficiencies 
Fig. 6. Sensitivity of economically viable area for reforestation to variation in carbon risk discounting factor, economic discount rate, establishment costs, and transaction and maintenance costs under the payment per tonne scheme (High cost: ec $=\mathrm{A} \$ 6000 / \mathrm{yr}, \mathrm{tmc}=\mathrm{A} \$ 100 / \mathrm{yr} ;$ Median cost: ec $=\mathrm{A} \$ 2000 / \mathrm{yr}, \mathrm{tmc}=\mathrm{A} \$ 70 / \mathrm{yr} ;$ Low cost: ec $=\mathrm{A} \$ 1150 / \mathrm{yr}, \mathrm{tmc}=\mathrm{A} \$ 40 / \mathrm{yr})$.

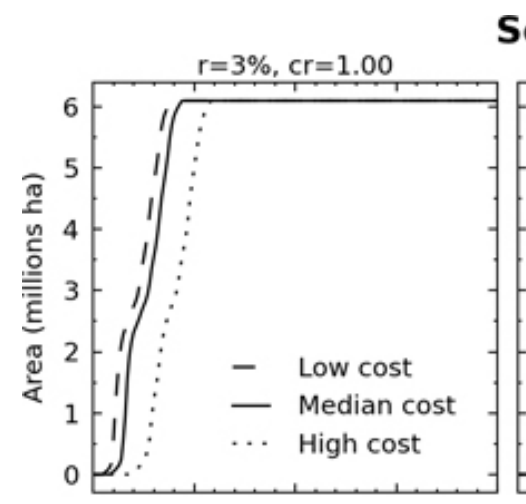

Sensitivity analysis
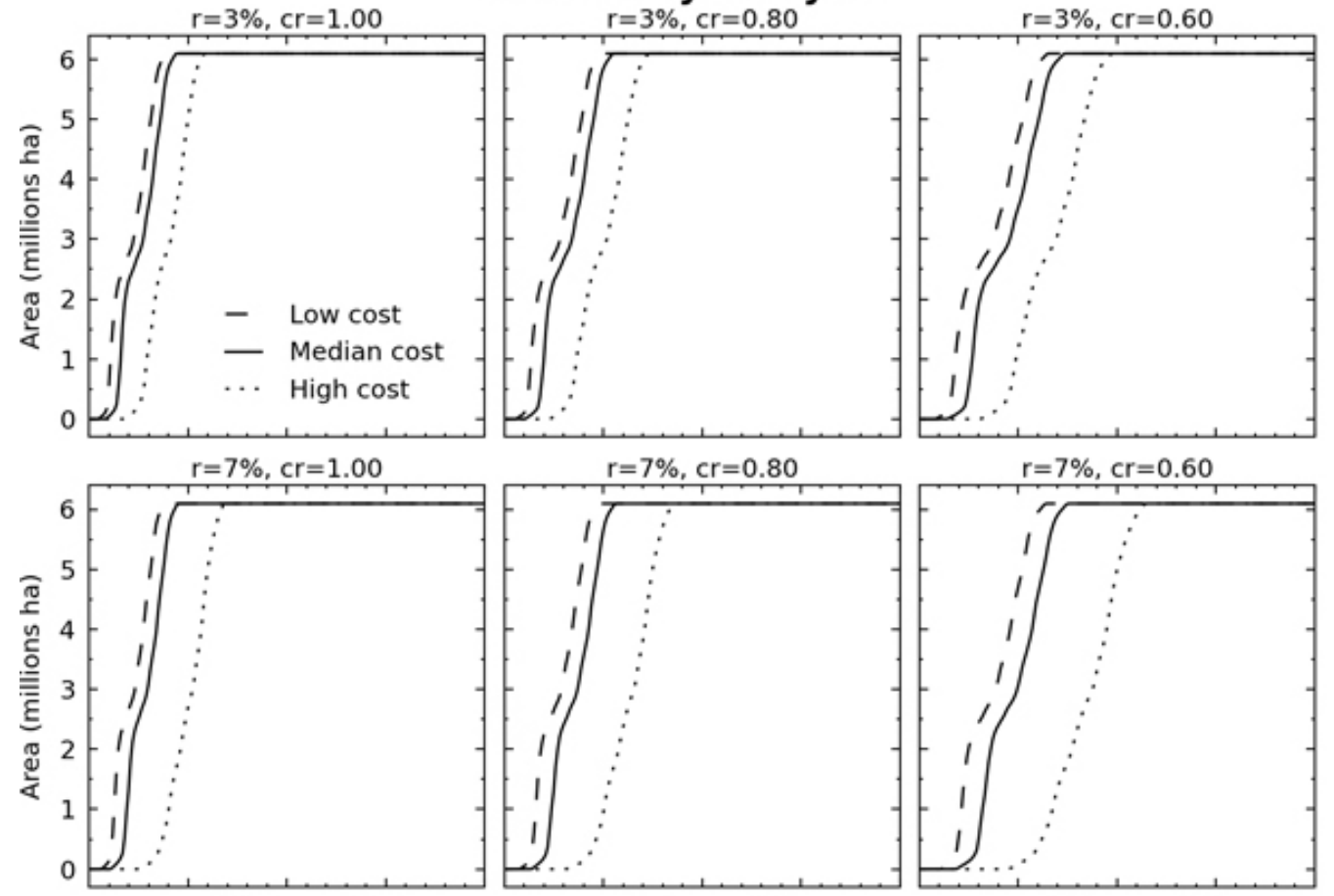

$\mathrm{r}=7 \%, \mathrm{cr}=0.60$
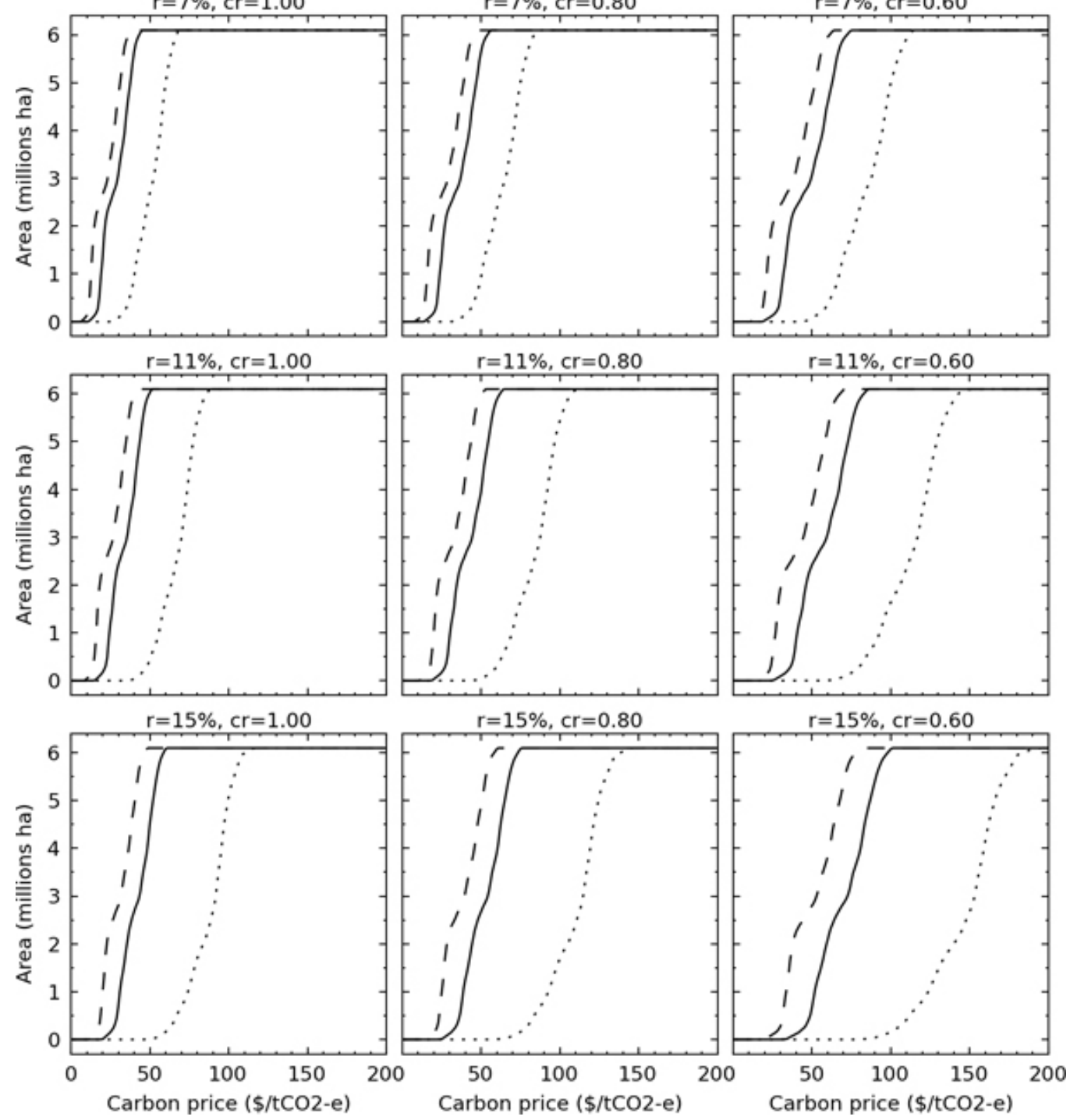
very near Pareto-optimal (section 3.2). This is consistent with theory (Babcock et al. 1997, Wu and Boggess 1999) as the benefits have a very low variance $(\mathrm{COV}=14 \%)$ compared with costs $(\mathrm{COV}=64 \%)$. Hence, replacing the heterogeneous benefit with the homogeneous proxy does not significantly affect the economic returns to reforestation.

Fig. 7. Sensitivity of food-carbon trade-offs and efficiency of the payment schemes to changes in economic parameters (High cost scenario: ec $=\mathrm{A} \$ 6000 / \mathrm{ha}, \mathrm{tmc}=\mathrm{A} \$ 100 / \mathrm{ha} / \mathrm{yr}, \mathrm{r}$ $=15 \%$; Median cost scenario: $\mathrm{ec}=\mathrm{A} \$ 2000 / \mathrm{ha}, \mathrm{tmc}=\mathrm{A} \$ 70 /$ $\mathrm{ha} / \mathrm{yr}, \mathrm{r}=0.07$; Low cost scenario: $\mathrm{ec}=\mathrm{A} \$ 1150 / \mathrm{ha}$, tmc $=$ $\mathrm{A} \$ 40 / \mathrm{ha} / \mathrm{yr}, \mathrm{r}=0.03$ ).
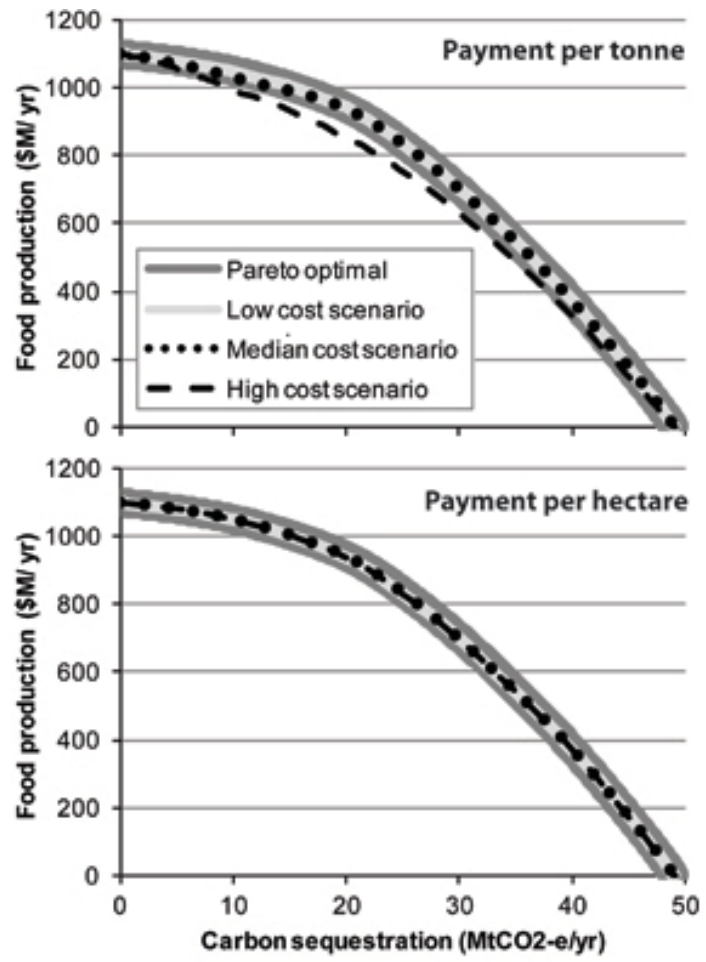

Increasing costs and discount rates decreased the efficiency of the payment per tonne scheme, but did not affect the efficiency of the payment per hectare scheme. Under the payment per hectare scheme profits from carbon sequestration are homogeneous so absolute advantage in agricultural production determines the relative profitability of carbon sequestration for each land unit. Increasing establishment costs and discount rates reduced the attractiveness of carbon sequestration, and shifted its supply, but did so in the same way for each land unit. Agricultural profits were not affected. Hence, the relative profitability of carbon sequestration between land units was not affected by changes in these parameters, and neither was efficiency. Conversely, under the payment per tonne scheme, increasing establishment costs and discount rates affected the profitability of carbon sequestration differently for each land unit. High establishment costs and discount rates can distort the relative profitability of reforestation, leading to allocative inefficiency in land use. This is reflected by the inward shift in the trade-off curve (Fig. 7).

To create a tradable commodity the amount of carbon sequestered must be verified, thereby incurring monitoring costs (these costs are not considered in this study). Monitoring costs affect the overall efficiency of a payment scheme. The magnitude of these costs will be highly dependent upon policy design with the payment per hectare scheme potentially having less need for rigorous measurement of carbon sequestration, and hence lower administration costs. Previous findings have varied with some studies (Parks and Hardie 1995, Stavins 1999) suggesting that the extra costs associated with measurement of carbon sequestration were likely to outweigh efficiency gains from using a policy that accounts for both costs and benefits. On the other hand, others have found that efficiency gains from accounting for farm scale variation in soil carbon sequestration often outweighed increased transaction costs (Antle 2003). These equivocal findings highlight the importance of context-specific assessment for informing efficient policy design.

The high efficiency of the payment per hectare scheme, its robustness to variation in economic parameters, as well as the potential for lower administration costs, may make this policy alternative an attractive option. However, moral hazard associated with the payment per hectare scheme poses a significant risk. The payment per tonne scheme provides landholders with incentives to ensure that carbon sequestration is validated and maintained. It may promote technological innovation by landholders leading to increased efficiency (Antle 2003). Additional contractual requirements may be necessary under the payment per hectare scheme to ensure that due care is taken in the establishment and maintenance phases of reforestation. Such an input-based contract, combined with regular compliance checks, may incur lower costs than measurement of carbon sequestered in forests required under the payment per tonne scheme, while maintaining a high level of compliance. The effectiveness of input standards depends upon the clear specification of inputs although higher levels of specificity will increase costs of ensuring that inputs are met.

\section{Limitations and future directions}

\section{Refinement and validation}

Relative variance of carbon sequestration and agricultural production are key determinants of food-carbon trade-offs under alternative payment schemes. We modeled the spatial distribution of these processes by integrating a range of economic and biophysical data that vary in their spatial scale and detail affecting relative variance in costs and benefits. Future work should focus on refining and validating the factors 
driving this relative variability. Landholder surveys can be an effective approach for validating landscape-scale modeling (Bryan et al. 2011a). A key parameter to reassess is the assumption of homogeneous establishment costs. The 3-PG modeling used also has limitations. To date, there have been few opportunities for validation of mallee species parameter files in the study area. Ongoing refinements are being made to both the model and species growth parameters. Increasing the spatial refinement of the model is a useful direction for future research. Higher resolution studies can capture the potential of small scale reforestation, e.g., agroforestry, strip plantings, which can also have positive feedbacks for agricultural productivity, e.g., through provision of livestock shelter, water table maintenance, erosion control. Significant potential exists for mixed production to increase carbon sequestration with minimal losses to agricultural production (Monjardino et al. 2010).

\section{Landholder decision making}

We assessed carbon sequestration based on economic profitability. Although this is a common approach for policy assessment (Antle and Valdivia 2006, Bryan et al. 2008, $2010 a, 2010 b$, Hunt 2008, Dymond et al. 2012), in reality many other factors also affect actual land use decision making (Pannell et al. 2011). Many of these factors that include personal values, preferences, attitudes, and situations, e.g., health, are difficult to quantify over large areas, although attempts are being made (e.g., Raymond et al. 2009). Empirical analyses using land use change observations to estimate costs of reforestation have found that landholders often retain existing practices after it is profitable to change land use (Plantinga et al. 2001, Lubowski et al. 2008). The rational desire of landholders to take time to investigate and trial new technologies (Pannell et al. 2011) may account for delayed uptake of new land uses. Uncertainty about future prices attaches an option value to the status quo (Plantinga et al. 2002). Once changed, costs of converting land use are sunk, and a return to the original land use will impose extra costs, and for reforestation these are likely to be high. Delaying land use conversion retains the option of future land use conversion. An empirical analysis of agricultural plots in Georgia, USA, found that the option value of a land asset can range from 7\% to $81 \%$ of its expected value (Schatzki 2003). Extending the static net present value framework used in this paper to consider price and production volatility within an option value framework is likely to increase the predictive power of the results. There are also significant limits to physical capacity, e.g., labor, seed stock, machinery, capital, that can affect rates of reforestation. Expansion of eucalypt and pine plantations over the past 20 years was restricted by availability of these resources, despite incentives from state and federal governments and managed investment schemes to increase plantations (Polglase et al. 2011). Future rates of reforestation are highly uncertain and depend upon the design of policy and institutional arrangements.
Other cobenefits and trade-offs

Although we focus here on food-carbon trade-offs, other cobenefits and trade-offs associated with the reforestation of agricultural land under a carbon market also exist. Reforestation can have substantial cobenefits for: economic development, through increased landholder incomes (Bryan et al. 2011b); biodiversity, through environmental plantings (Crossman et al. 2011); soils, through reduced erosion and salinization (Bartle et al. 2007, Harper et al. 2007); and energy security, through bioenergy processing (Bryan et al. 2008, $2010 a, 2010 b$ ). However, reforestation may also have other socioeconomic and environmental costs such as reduced water availability. Integrated assessment of reforestation impacts is required to fully account for interactions between complex cobenefits and trade-offs, which vary with location, type, and area of reforestation, and the preferences and values of society (Nelson et al. 2008, 2009, Bryan et al. 2011b). Consideration of the value of cobenefits and trade-offs for ecosystem services for both reforestation and agriculture will change the relative economic viability of these land uses. Understanding these trade-offs and cobenefits, especially how they vary under climate change, is the focus of ongoing work.

\section{CONCLUSION}

We have combined detailed spatio-temporal biophysical and economic information to assess food-carbon trade-offs and policy under two common carbon payment schemes. The relative ability of land units to sequester carbon and produce food was heterogeneous across the study area leading to convex production frontiers reflecting food-carbon trade-offs. The nature of these trade-offs highlight the potential to sequester carbon in the landscape with a limited impact on agricultural production. Our analysis of both payment per tonne and payment per hectare schemes suggests that both policy instruments may achieve very efficient outcomes. Variation in model parameters had a strong effect on the price of carbon at which reforestation became more profitable than agriculture and affected the efficiency of the payment per tonne scheme, but not the payment per hectare scheme. This robustness and potential for reduced transaction costs are attractive qualities of the payment per hectare scheme although the risks of moral hazard under this scheme need to be carefully managed. The results can inform the design of policy and have illuminated factors that may be important for future consideration of policy efficiency. Further work to better develop the land use decision model will further improve our understanding of food-carbon trade-offs.

Responses to this article can be read online at: http://www.ecologyandsociety.org/voll7/iss3/art21/ responses/ 


\section{Acknowledgments:}

We are grateful for the support of CSIROs Integrated Carbon Pathways project and Sustainable Agriculture Flagship, and the Land Technologies Alliance. We thank all the agencies and individuals who supplied us with data, especially Jenny Carter (CSIRO) for the 3-PG species parameter file. Stephanie McWhinnie helped guide the research and comments from Jeff Connor and Michael Battaglia improved the manuscript.

\section{LITERATURE CITED}

Alexandrov, G. A. 2008. Forest growth in the light of the thermodynamic theory of ecological systems. Ecological Modelling 216:102-106.

Alig, R., G. Latta, D. Adams, and B. McCarl. 2010. Mitigating greenhouse gases: the importance of land base interactions between forests, agriculture, and residential development in the face of changes in bioenergy and carbon prices. Forest Policy and Economics 12:67-75. http://dx.doi.org/10.1016/j.f orpol.2009.09.012

Antle, J. 2003. Spatial heterogeneity, contract design, and the efficiency of carbon sequestration policies for agriculture. Journal of Environmental Economics and Management 46:231-250. http://dx.doi.org/10.1016/S0095-0696(02)00038-4

Antle, J. M., and R. O. Valdivia. 2006. Modelling the supply of ecosystem services from agriculture: a minimum-data approach. Australian Journal of Agricultural and Resource Economics 50:1-15. http://dx.doi.org/10.1111/j.1467-8489.20 06.00315.X

Babcock, B. A., P. G. Lakshminarayan, J. J. Wu, and D. Zilberman. 1997. Targeting tools for the purchase of environmental amenities. Land Economics 73:325-339. http:/ /dx.doi.org/10.2307/3147171

Bartle, J., G. Olsen, D. Cooper, and T. Hobbs. 2007. Scale of biomass production from new woody crops for salinity control in dryland agriculture in Australia. International Journal of Global Energy Issues 27:115-137. http://dx.doi.org/10.1504/I JGEI.2007.013652

Bryan, B. A., N. D. Crossman, D. King, and W. S. Meyer. $2011 b$. Landscape futures analysis: assessing the impacts of environmental targets under alternative spatial policy options and future scenarios. Environmental Modelling \& Software 26:83-91. http://dx.doi.org/10.1016/j.envsoft.2010.03.034

Bryan, B. A., S. Hajkowicz, S. Marvanek, and M. D. Young. 2009. Mapping economic returns to agriculture for informing environmental policy in the Murray-Darling Basin, Australia. Environmental Modeling \& Assessment 14:375-390. http://dx. doi.org/10.1007/s10666-008-9144-8
Bryan, B. A., D. King, and E. Wang. 2010a. Potential of woody biomass production for motivating widespread natural resource management under climate change. Land Use Policy 27:713-725. http://dx.doi.org/10.1016/j.landusepol.2009.09.012

Bryan, B. A., D. King, and E. Wang. 2010b. Biofuels agriculture: landscape-scale trade-offs between fuel, economics, carbon, energy, food, and fiber. Global Change Biology Bioenergy 2:330-345. http://dx.doi.org/10.1111/j.175 7-1707.2010.01056.x

Bryan, B. A., D. King, and J. R. Ward. 2011a. Modelling and mapping agricultural opportunity costs to guide landscape planning for natural resource management. Ecological Indicators 11:199-208. http://dx.doi.org/10.1016/j.ecolind.20 $\underline{09.02 .005}$

Bryan, B. A., J. Ward, and T. Hobbs. 2008. An assessment of the economic and environmental potential of biomass production in an agricultural region. Land Use Policy 25:533-549. http://dx.doi.org/10.1016/j.landusepol.2007.11.003

Cacho, O. J., R. L. Hean, and R. M. Wise. 2003. Carbonaccounting methods and reforestation incentives. Australian Journal of Agricultural and Resource Economics 47:153-179. http://dx.doi.org/10.1111/1467-8489.00208

Cacho, O. J., G. R. Marshall, and M. Milne. 2005. Transaction and abatement costs of carbon-sink projects in developing countries. Environment and Development Economics 10:597-614. http://dx.doi.org/10.1017/S1355770X05002056

Cantarello, E., A. C. Newton, and R. A. Hill. 2011. Potential effects of future land-use change on regional carbon stocks in the UK. Environmental Science \& Policy 14:40-52. http://dx. doi.org/10.1016/j.envsci.2010.10.001

Chen, X., F. Lupi, A. Viña, G. He, and J. Liu. 2010. Using cost effective targeting to enhance the efficiency of conservation investments in payments for ecosystem services. Conservation Biology 24:1469-1478. http://dx.doi.org/10.1111/ j.1523-1739.2010.01551.x

Crossman, N. D., and B. A. Bryan. 2009. Identifying costeffective hotspots for restoring natural capital and enhancing landscape multifunctionality. Ecological Economics 68:654-668. http://dx.doi.org/10.1016/j.ecolecon.2008.05.003

Crossman, N. D., B. A. Bryan, and D. M. Summers. 2011. Carbon payments and low-cost conservation. Conservation Biology 25:835-845. http://dx.doi.org/10.1111/j.1523-1739.2 011.01649.x

DeFries, R. S., J. A. Foley, and G. P. Asner. 2004. Land-use choices: balancing human needs and ecosystem function. Frontiers in Ecology and the Environment 2:249-257. http://d 
x.doi.org/10.1890/1540-9295(2004)002[0249:LCBHNA]2.0. $\underline{\mathrm{CO} ; 2}$

Dymond, J. R., A.-G. E. Ausseil, J. C. Ekanayake, and M. U. F. Kirschbaum. 2012. Tradeoffs between soil, water, and carbon - a national scale analysis from New Zealand. Journal of Environmental Management 95:124-131. http://dx.doi.org/ 10.1016/j.jenvman.2011.09.019

Ferraro, P. J. 2003. Assigning priority to environmental policy interventions in a heterogeneous world. Journal of Policy Analysis and Management 22:27-43. http://dx.doi.org/10.1002/ pam.10094

Foley, J. A., R. DeFries, G. P. Asner, C. Barford, G. Bonan, S. R. Carpenter, F. S. Chapin, M. T. Coe, G. C. Daily, H. K. Gibbs, J. H. Helkowski, T. Holloway, E. A. Howard, C. J. Kucharik, C. Monfreda, J. A. Patz, I. C. Prentice, N. Ramankutty, and P. K. Snyder. 2005. Global consequences of land use. Science 309:570-574. http://dx.doi.org/10.1126/scie nce. 1111772

Golub, A., T. Hertel, H.-L. Lee, S. Rose, and B. Sohngen. 2009. The opportunity cost of land use and the global potential for greenhouse gas mitigation in agriculture and forestry. Resource and Energy Economics 31:299-319. http://dx.doi.or $\mathrm{g} / 10.1016 / \mathrm{j}$. reseneeco.2009.04.007

Harper, R. J., A. C. Beck, P. Ritson, M. J. Hill, C. D. Mitchell, D. J. Barrett, K. R. J. Smettem, and S. S. Mann. 2007. The potential of greenhouse sinks to underwrite improved land management. Ecological Engineering 29:329-341. http://dx.d oi.org/10.1016/j.ecoleng.2006.09.025

Higgins, A. J., S. Hajkowicz, and E. Bui. 2008. A multiobjective model for environmental investment decision making. Computers \& Operations Research 35:253-266. http ://dx.doi.org/10.1016/j.cor.2006.02.027

Hunt, C. 2008. Economy and ecology of emerging markets and credits for bio-sequestered carbon on private land in tropical Australia. Ecological Economics 66:309-318. http://d x.doi.org/10.1016/j.ecolecon.2007.09.012

Irwin, E. G., and J. Geoghegan. 2001. Theory, data, methods: developing spatially explicit economic models of land use change. Agriculture Ecosystems \& Environment 85:7-24. htt p://dx.doi.org/10.1016/S0167-8809(01)00200-6

Landsberg, J. J., and R. H. Waring. 1997. A generalised model of forest productivity using simplified concepts of radiationuse efficiency, carbon balance and partitioning. Forest Ecology and Management 95:209-228. http://dx.doi.org/10.1 016/S0378-1127(97)00026-1

Lawson, K., K. Burns, K. Low, E. Heyhoe, and H. Ahammad. 2008. Analysing the economic potential of forestry for carbon sequestration under alternative carbon price paths. Australian Bureau of Agricultural and Resource Economics, Canberra,
Australia. [online] URL: http://archive.treasury.gov.au/lowpo llutionfuture/consultants report/downloads/Economic Poten tial of Forestry.pdf

Lubowski, R. N., A. J. Plantinga, and R. N. Stavins. 2006. Land-use change and carbon sinks: econometric estimation of the carbon sequestration supply function. Journal of Environmental Economics and Management 51:135-152. htt p://dx.doi.org/10.1016/j.jeem.2005.08.001

Lubowski, R. N., A. J. Plantinga, and R. N. Stavins. 2008. What drives land-use change in the United States? A national analysis of landowner decisions. Land Economics 84:529-550.

Monjardino, M., D. Revell, and D. J. Pannell. 2010. The potential contribution of forage shrubs to economic returns and environmental management in Australian dryland agricultural systems. Agricultural Systems 103:187-197. http ://dx.doi.org/10.1016/j.agsy.2009.12.007

Nelson, E., G. Mendoza, J. Regetz, S. Polasky, H. Tallis, D. R. Cameron, K. M. A. Chan, G. C. Daily, J. Goldstein, P. M. Kareiva, E. Lonsdorf, R. Naidoo, T. H. Ricketts, and M. R. Shaw. 2009. Modeling multiple ecosystem services, biodiversity conservation, commodity production, and tradeoffs at landscape scales. Frontiers in Ecology and the Environment 7:4-11. http://dx.doi.org/10.1890/080023

Nelson, E., S. Polasky, D. J. Lewis, A. J. Plantinga, E. Lonsdorf, D. White, D. Bael, and J. J.Lawler. 2008. Efficiency of incentives to jointly increase carbon sequestration and species conservation on a landscape. Proceedings of the National Academy of Sciences of the United States of America 105:9471-9476. http://dx.doi.org/10.1073/pnas.0706178105

Newburn, D., S. Reed, P. Berck, and A. Merenlender. 2005. Economics and land-use change in prioritizing private land conservation. Conservation Biology 19:1411-1420. http://dx. doi.org/10.1111/j.1523-1739.2005.00199.x

Obersteiner, M., H. Böttcher, and Y. Yamagata. 2010. Terrestrial ecosystem management for climate change mitigation. Current Opinion in Environmental Sustainability 2:271-276. http://dx.doi.org/10.1016/j.cosust.2010.05.006

Palm, C. A., S. M. Smukler, C. C. Sullivan, P. K. Mutuo, G. I. Nyadzi, and M. G. Walsh. 2010. Identifying potential synergies and trade-offs for meeting food security and climate change objectives in sub-Saharan Africa. Proceedings of the National Academy of Sciences of the United States of America 107:19661-19666. http://dx.doi.org/10.1073/pnas.0912248107

Pannell, D., G. R. Marshall, N. Barr, F. Vanclay, and R. Wilkinson. 2011. Adoption of new practises by rural landholders. Pages 11-39 in D. Pannell and F. Vanclay, editors. 
Changing land management. CSIRO Publishing, Collingwood, Victoria, Australia.

Parks, P. J., and I. W. Hardie. 1995. Least-cost forest carbon reserves: cost-effective subsidies to convert marginal agricultural land to forests. Land Economics 71:122-136. htt p://dx.doi.org/10.2307/3146763

Plantinga, A. J., R. Alig, and H. T. Cheng. 2001. The supply of land for conservation uses: evidence from the conservation reserve program. Resources, Conservation and Recycling 31:199-215. http://dx.doi.org/10.1016/S0921-3449(00)00085-9

Plantinga, A. J., R. N. Lubowski, and R. N. Stavins. 2002. The effects of potential land development on agricultural land prices. Journal of Urban Economics 52:561-581. http://dx.doi. org/10.1016/S0094-1190(02)00503-X

Plantinga, A. J., T. Mauldin, and D. J. Miller. 1999. An econometric analysis of the costs of sequestering carbon in forests. American Journal of Agricultural Economics 81:812-824. http://dx.doi.org/10.2307/1244326

Polasky, S., E. Nelson, J. Camm, B. Csuti, P. Fackler, E. Lonsdorf, C. Montgomery, D. White, J. Arthur, B. GarberYonts, R. Haight, J. Kagan, A. Starfield, and C. Tobalske. 2008. Where to put things? Spatial land management to sustain biodiversity and economic returns. Biological Conservation 141:1505-1524. http://dx.doi.org/10.1016/j.biocon.2008.03.022

Polglase, P., K. Paul, C. Hawkins, A. Siggins, J. Turner, T. Booth, D. Crawford, T. Jovanovic, T. Hobbs, K. Opie, A. Almeida, and J. Carter. 2008. Regional opportunities for agroforestry systems in Australia. Rural Industries Research and Development Corporation, Canberra, Australia. [online] URL: https://rirdc.infoservices.com.au/downloads/08-176

Polglase, P., A. Reeson, C. Hawkins, K. Paul, A. Siggins, J. Turner, D.Crawford, T. Jovanovic, T. Hobbs, K. Opie, J. Carwardine, and A. Almeida. 2011. Opportunities for carbon forestry in Australia: economic assessment and constraints to implementation. CSIRO Technical Report, CSIRO Publishing, Collingwood, Victoria, Australia. [online] URL: http://www.csiro.au/files/files/p10tz.pdf

Raymond, C. M., B. A. Bryan, D. H. MacDonald, A. Cast, S. Strathearn, A. Grandgirard, and T. Kalivas. 2009. Mapping community values for natural capital and ecosystem services. Ecological Economics 68:1301-1315. http://dx.doi.org/10.1016/ j.ecolecon.2008.12.006

Reserve Bank of Australia (RBA). 2010. Cash Rate Target 2001-2010. Reserve Bank of Australia, Sydney, Australia.

Richards, F. J. 1959. A flexible growth function for empirical use. Journal of Experimental Botany 10:290-301. http://dx.do i.org/10.1093/jxb/10.2.290
Schatzki, T. 2003. Options, uncertainty and sunk costs: an empirical analysis of land use change. Journal of Environmental Economics and Management 46:86-105. http: //dx.doi.org/10.1016/S0095-0696(02)00030-X

Smith, P., P. J. Gregory, D. van Vuuren, M. Obersteiner, P. Havlik, M. Rounsevell, J. Woods, E. Stehfest, and J. Bellarby. 2010. Competition for land. Philosophical Transactions of the Royal Society B-Biological Sciences 365:2941-2957. http://dx .doi.org/10.1098/rstb.2010.0127

Stavins, R. N. 1999. The costs of carbon sequestration: a revealed-preference approach. American Economic Review 89:994-1009. http://dx.doi.org/10.1257/aer.89.4.994

Stoms, D. M., J. Kreitler, and F. W. Davis. 2011. The power of information for targeting cost-effective conservation investments in multifunctional farmlands. Environmental Modelling \& Software 26:8-17. http://dx.doi.org/10.1016/j.en vsoft.2010.03.008

Thomson, A. M., K. V. Calvin, L. P. Chini, G. Hurtt, J. A. Edmonds, B. Bond-Lamberty, S. Frolking, M. A. Wise, and A. C. Janetos. 2010. Climate mitigation and the future of tropical landscapes. Proceedings of the National Academy of Sciences 107:19633-19638. http://dx.doi.org/10.1073/pnas.09 $\underline{10467107}$

Tilman, D., R. Socolow, J. A. Foley, J. Hill, E. Larson, L. Lynd, S. Pacala, J. Reilly, T. Searchinger, C. Somerville, and R. Williams. 2009. Beneficial biofuels - the food, energy, and environment trilemma. Science 325:270-271. http://dx.doi.or $\mathrm{g} / 10.1126 /$ science. 1177970

Van der Werf, E., and S. Peterson. 2009. Modeling linkages between climate policy and land use: an overview. Agricultural Economics 40:507-517. http://dx.doi.org/10.1111/ j.1574-0862.2009.00394.x

Wätzold, F., and M. Drechsler. 2005. Spatially uniform versus spatially heterogeneous compensation payments for biodiversity-enhancing land-use measures. Environmental and Resource Economics 31:73-93. http://dx.doi.org/10.1007/ s10640-004-6979-6

West, P. C., H. K. Gibbs, C. Monfreda, J. Wagner, C. C. Barford, S. R. Carpenter, and J. A. Foley. 2010. Trading carbon for food: global comparison of carbon stocks vs. crop yields on agricultural land. Proceedings of the National Academy of Sciences of the United States of America 107:19645-19648. http://dx.doi.org/10.1073/pnas.1011078107

Wise, M., K. Calvin, A. Thomson, L. Clarke, B. BondLamberty, R. Sands, S. J. Smith, A. Janetos, and J. Edmonds. 2009. Implications of limiting $\mathrm{CO}_{2}$ concentrations for land use and energy. Science 324:1183-1186. http://dx.doi.org/10.1126/ science. 1168475 
Wu, J. J., and W. G. Boggess. 1999. The optimal allocation of conservation funds. Journal of Environmental Economics and Management 38:302-321. http://dx.doi.org/10.1006/jeem .1999 .1091

Zhao-gang, L., and L. Feng-ri. 2003. The generalized Chapman-Richards function and applications to tree and stand growth. Journal of Forestry Research 14:19-26. http://dx.doi. org/10.1007/BF02856757 